pants of small boats to wear a life-jacket capable of keeping the face above water, and the danger in trying to swim even short distances to shore in cold water without one.

We are indebted to $\mathrm{Mr}$. B. Cobern for his skilled technical assistance.

\section{REFERENCES}

Critchley, M. (1943). Shipwreck Survivors: A Medical Study, p. 7. London.
Glaser, E. M., and Hervey, G. R. (1951). 7. Physiol. (Lond.), 115, 14P.

Keatinge, W. R. (1965). Brit. med. F., 2, 1537.

Keatinge, W. R. (1969). Survival in Cold Water: The Physiology and Treatment of Immersion Hypothermia and of Drowning, pp. 30-35. Oxford.

Keatinge, W. R., and Evans, M. (1961). Quart. 7. exp. Physiol., 46, 83 Keatinge, W. R., McIlroy, M. B., and Goldfien, A. (1964). F. appl. Physiol., 19, 1145 .

Keatinge, W. R., and Nadel, J. A. (1965). 7. appl. Physiol., 20, 65.

Li, C.-L. (1958). Amer. F. Physiol., 194, 200.

Lind, A. R. (1959). F. Physiol. (Lond.), 147, 162.

McCance, R. A., Ungley, C. C., Crosfill, J. W. L., and Widdowson, E. M. (1956). Spec. Rep. Ser. med. Res. Coun. (Lond.), No. 291

Molnar, G. W. (1946). F. Amer. med. Ass., 131, 1046.

Nukada, A. (1955). Int. Z. angew. Physiol., 16, 74.

\title{
Turner's Infantile Phenotype
}

\author{
R. R. GORDON,* M.C., M.D., F.R.C.P. ; EILEEN M. O’NEILL, $\dagger$ M.D., M.R.C.P., D.C.H.
}

Brit. med.F., 1969, 1, 483-485

\begin{abstract}
Cummary : Turner's infantile phenotype is a term used $\checkmark$ to describe infants with stigmata suggestive of Turner's syndrome. These include brawny oedema of the feet, loose neck folds, and a characteristic facies. Ten cases are described in this report. Four of these had a similar facial appearance and three had serous effusions. Two of the latter died and at necropsy no cardiac, vascular, or renal cause for the effusions was found, but the gonads in each were macroscopically reduced in size and microscopically were grossly abnormal.
\end{abstract}

\section{Introduction}

Originally Turner's syndrome consisted of dwarfism, cubitus valgus, neck webbing, and infantilism in a female who should, by age, have been mature (Turner, 1938). Wilkins and Fleischmann (1944) showed that the infantilism was due to failure of gonadal development (" gonadal dysgenesis" ; "streak gonads") and this is now an accepted part of the syndrome (Jones et al., 1966). Ferguson-Smith (1965) proposed that the failure of gonadal development was due to absence of genes on the short arm of a second sex chromosome and that the dwarfism might also be explained in this way. Certainly there is a strong association between the $45 \mathrm{X}$ chromosomal state (with all its variations) and the clinical features of Turner's syndrome (and all its "atypical" forms).

Since the original description somatic features additional to dwarfism, neck webbing, and cubitus valgus have been described and the list of these Turner stigmata is now formidable (Table I). When a young girl presents with small stature and lack of secondary sex characteristics it is usually the presence of some Turner stigmata which suggests the diagnosis of Turner's syndrome. If such a person is shown to be chromatinnegative with a $45 \mathrm{X}$ karyotype the diagnosis is almost certain. The finding of streak gonads at laparotomy is final proof. However, even when such a girl is chromatin-positive streak gonads may still be present if she is an $\mathrm{X} / \mathrm{XX}$ mosaic or has a 46XXqi karyotype. On the other hand, Turner stigmata may be associated with perfectly normal ovarian development in an XX girl-the syndrome of Ullrich (Polani, 1961). In

* Consultant Paediatrician, Children's Hospital, Sheffield 10. t Consultant Paediatrician, Barnsley Group of Hospitals. such cases the Turner stigmata are probably genetically rather than chromosomally determined (Nora and Sinha, 1967).

$$
\text { TABLE I.-Turner Stigmata (Haddad and Wilkins, 1959) }
$$

\begin{tabular}{l|l} 
*1. Shield chest & *11. Lymphoedema \\
2. Overweight & 12. Cutis laxa \\
*3. High palate & 13. Keloid formation \\
*4. Micrognathia & 14. Coarctation of aorta \\
*5. Epicanthus & 15. Mental retardation \\
*6. Low-set ears & 16. Intestinal telangiectasia \\
*7. Hypoplasia of nails & 17. Deafness \\
8. Osteoporosis & 18. Short fourth metacarpals \\
9. Pigmented moles & 19. Urinary tract anomalies \\
10. Hypertension & * These features make up Turner's infantile phenotype.
\end{tabular}

Turner stigmata may also be present in males, but the expression "male Turner's syndrome" has always been contradictory and unsatisfactory.

Even in the older child, therefore, the nomenclature is confusing, but in the younger child it is more so. This is because we do not measure height and sexual maturation definitively until the teenage years. Yet it is obviously of importance to diagnose early those children who will later have Turner's syndrome, before the age at which they will require treatment. The earlier the diagnosis is made the easier should be the management and the more satisfactory the treatment.

The Bonnevie-Ullrich syndrome describes infant females with some Turner stigmata. The ones most commonly found are indicated in Table I. Such infants are not unduly short and it is not until about the age of 5 years that dwarfism can be clearly seen (Wilkins, 1965). They will, however, often be chromatin-negative and have $45 \mathrm{X}$ chromosomes. But can we say they have Turner's syndrome ? At the moment we cannot.

Jones et al. (1966) suggested that the expression "Turner's phenotype " should be used to indicate the presence of sufficient Turner stigmata to arouse the clinical suspicion of Turner's syndrome but that unless dwarfism and streak gonads are confirmed the term should be suitably qualified. Thus " male Turner's syndrome" would become "Turner's male phenotype " and Ullrich's syndrome would become "Turner's phenotype with normal ovaries." On this basis the BonnevieUllrich syndrome could become "Turner's infantile phenotype." It is usually recognized in the neonatal period from the presence of oedema of feet and loose neck folds. The oedema is brawny but pits on pressure ; it occasionally also affects the hands. Both the oedema and the loose neck folds 
tend to disappear by the age of 1 year and the neck folds are sometimes replaced by a webbed neck. There is also said to be a typical facies made up of the facial features listed in Table I.

Recent descriptions of Turner's infantile phenotype have been few, though Jacobs and Keay in 1959 showed its association with streak gonads and a single $\mathrm{X}$ chromosome. Frøland et al. (1963) described two cases, and one of these infants died during the newborn period from heart failure due to severe coarctation of the aorta. Conen and Glass (1963) described two cases which probably had $45 \mathrm{X}$ chromosomes, but it is possible that their Case 2 was a $45 \mathrm{X} / 46 \mathrm{XX}$ mosaic, since one ovary was entirely normal, the other being a "streak." In both of these cases death was attributed to hypoplasia of the aortic arch with subsquent heart failure. Carr et al. (1968) also described the case of a neonate with typical clinical features who died from heart failure, which at necropsy was shown to be due to severe aortic valvular stenosis, but there was no aortic coarctation or hypoplasia. The gonads in this case were small but did show a few primordial follicles on microscopy. Similar findings were reported by Hodel and Egli (1965).

Table II indicates briefly our experience with 10 infants who presented within the first six months of life. Two of them died and three showed features which have never been described before.

TABLE II

\begin{tabular}{|c|c|c|c|c|c|c|c|c|c|c|}
\hline \multirow{2}{*}{$\begin{array}{l}\text { Case } \\
\text { No. }\end{array}$} & \multirow{2}{*}{ 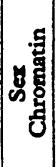 } & \multirow[t]{2}{*}{ Karyotype } & \multirow{2}{*}{$\begin{array}{c}\text { Referral } \\
\text { Age }\end{array}$} & \multicolumn{2}{|c|}{ Birth Weight } & \multirow{2}{*}{ 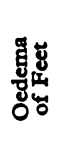 } & \multirow{2}{*}{ 号总总 } & \multirow{2}{*}{ 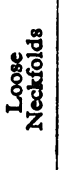 } & \multirow{2}{*}{ 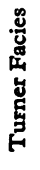 } & \multirow{2}{*}{ 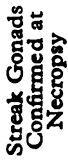 } \\
\hline & & & & 1b.oz. & g. & & & & & \\
\hline $\begin{array}{l}1 \\
2 \\
3 \\
4 \\
5 \\
6 \\
7 \\
8 \\
9 \\
10\end{array}$ & $\begin{array}{l}\bar{z} \\
\bar{z} \\
\bar{z} \\
\bar{t}\end{array}$ & \begin{tabular}{|c|}
$45 \mathrm{X}$ \\
$45 \mathrm{X}$ \\
$45 \mathrm{X}$ \\
$45 \mathrm{X}$ \\
$45 \mathrm{X}$ \\
$45 \mathrm{X}$ \\
$?$ \\
$45 \mathrm{X}$ \\
$45 \mathrm{X}$ \\
$45 \mathrm{X} / 46 \mathrm{XXqi}$
\end{tabular} & $\begin{array}{l}\text { Birth } \\
4 \text { months } \\
8 \text { days } \\
\text { Birth } \\
\text { Birth } \\
1 \text { day } \\
\text { Birth } \\
9 \text { days } \\
6 \text { months } \\
4 \text { months }\end{array}$ & $\begin{array}{rr}6 & 13 \\
4 & 6 \\
5 & 0 \\
7 & 8 \\
7 & 8 \\
6 & 10 \\
6 & 4 \\
7 & 5 \\
7 & 2 \\
6 & 3\end{array}$ & $\begin{array}{l}3,090 \\
1,980 \\
2,270 \\
3,400 \\
3,400 \\
3,000 \\
2,835 \\
3,315 \\
3,230 \\
2,810\end{array}$ & $\begin{array}{l}+ \\
+ \\
+ \\
+ \\
+ \\
+ \\
+ \\
+ \\
+ \\
0\end{array}$ & $\begin{array}{l}0 \\
0 \\
0 \\
+ \\
0 \\
+ \\
+ \\
0 \\
0 \\
0\end{array}$ & $\begin{array}{l}+ \\
0 \\
+ \\
+ \\
0 \\
+ \\
+ \\
+ \\
+ \\
0\end{array}$ & $\begin{array}{l}+ \\
0 \\
+ \\
0 \\
0 \\
+ \\
0 \\
0 \\
0 \\
+\end{array}$ & $\begin{array}{l}+ \\
+\end{array}$ \\
\hline
\end{tabular}

\section{Discussion}

This collection of cases is remarkable in that 3 out of 10 had serous effusions, a finding not previously described. All three had ascites and pleural effusions and one also had a pericardial effusion. Though heart failure was suspected in two this diagnosis could not be upheld and none of the three had significant heart lesions. The patient (Case 7) who had all three types of effusion also had a very small atrial septal defect unlikely to be associated with heart failure; there was no

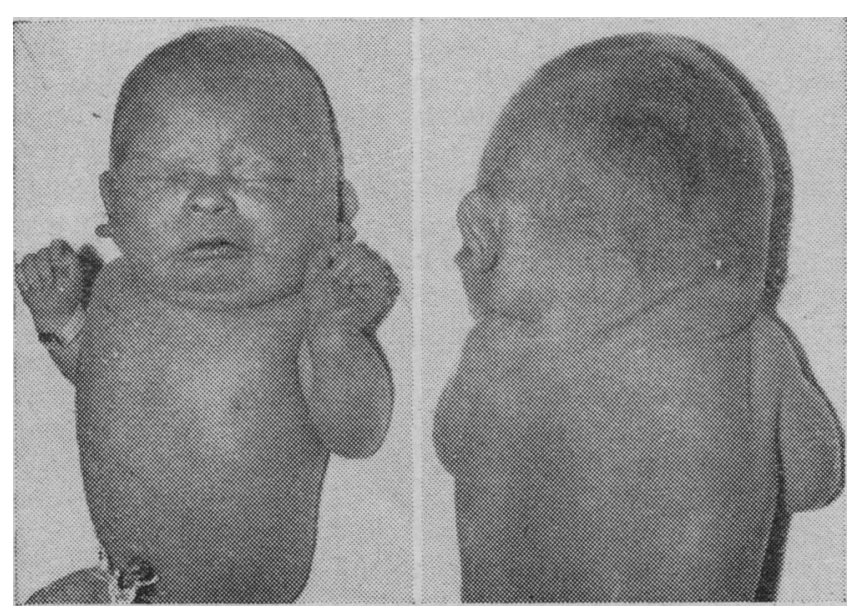

FIG. 1.-Case 4. Gross oedema of face and loose neck folds with distortion of ears from scalp oedema. hepatomegaly. Case 4 presented with gross generalized oedema, including oedema of her neck folds (Fig. 1). At necropsy large pleural effusions and ascites were confirmed. The heart was normal, with normal great arteries. Case 6 had oedema of the feet, a large right-sided pleural effusion (Fig. 2), and, almost certainly, ascites. This, like the oedema elsewhere, cleared spontaneously.

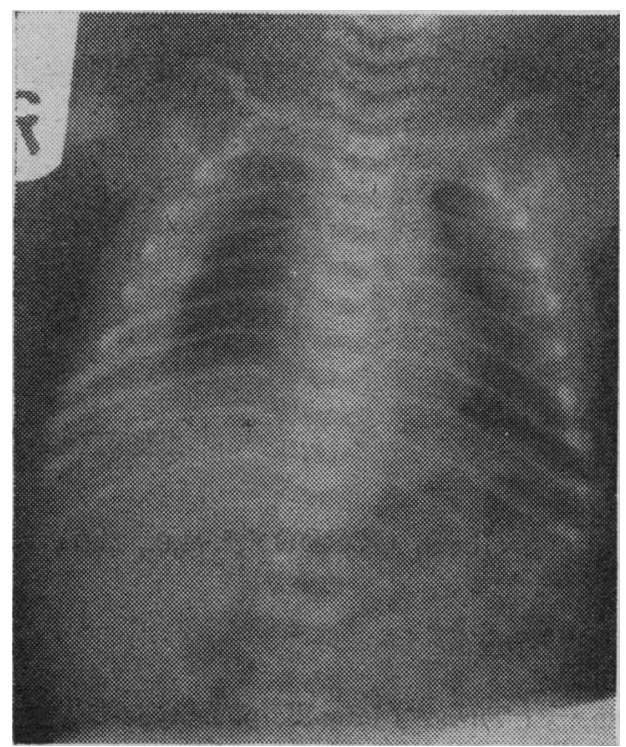

FIG. 2.-Case 6. Radiograph showing the rightsided pleural effusion, which cleared spontaneously.

In none of these three cases was any general cause found for the oedema and effusions and it was assumed that they were due to abnormal development of the lymphatic channels, this being the explanation for the oedema of feet (Benson et al., 1965).

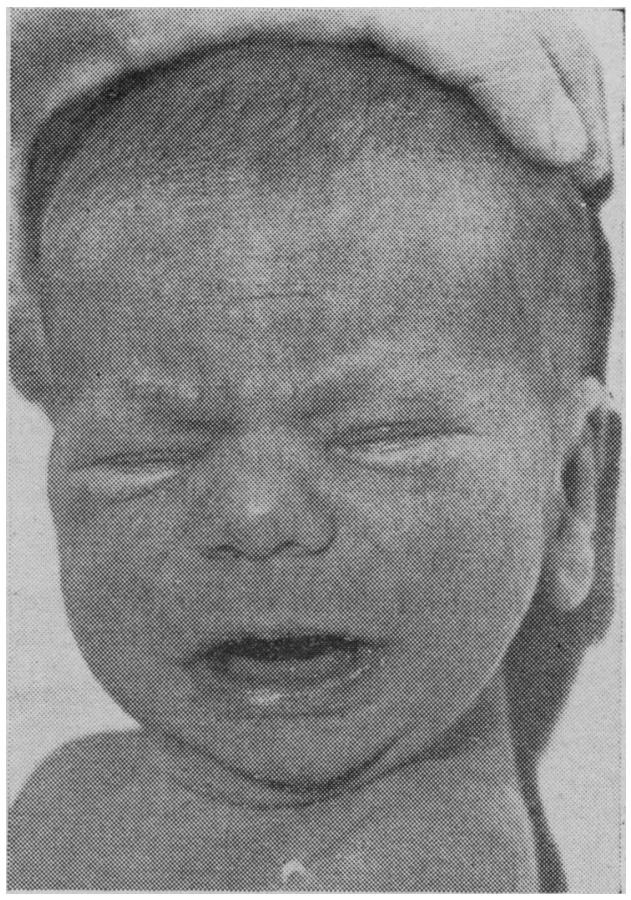

FIG. 3.-Case 3. Facial features sometimes found in Turner's infantile phenotype. The mouth is large, the nose squashed, and the eyes have folds below the lower lids. The chin is small and there are loose anterior neck folds.

Two of the three children with effusions died unexpectedly and without adequate explanation. Case 7 had mild respiratory distress at birth but this cleared after a few hours and she was 
then quite well until the third day, when she suddenly collapsed and died. Case 4 was oedematous when admitted at the age of a few hours. After diuretic treatment she lost $12 \mathrm{oz}$. $(340 \mathrm{~g}$.) in weight but at the age of 4 days she died suddenly. Neither child had coarctation of the aorta at necropsy or any other congenital cardiac malformation which could have contributed to death.

Another unusual mode of presentation was that of Case 10. She was recognized solely because of the similarity of her facial features to those of Case 3 (Figs. 3 and 4). She had none of the classical Turner stigmata but was referred because of failure to thrive. When she was found to be chromatin-positive the diagnosis was almost abandoned, but chromosome analysis showed her to be an X/XXqi mosaic.

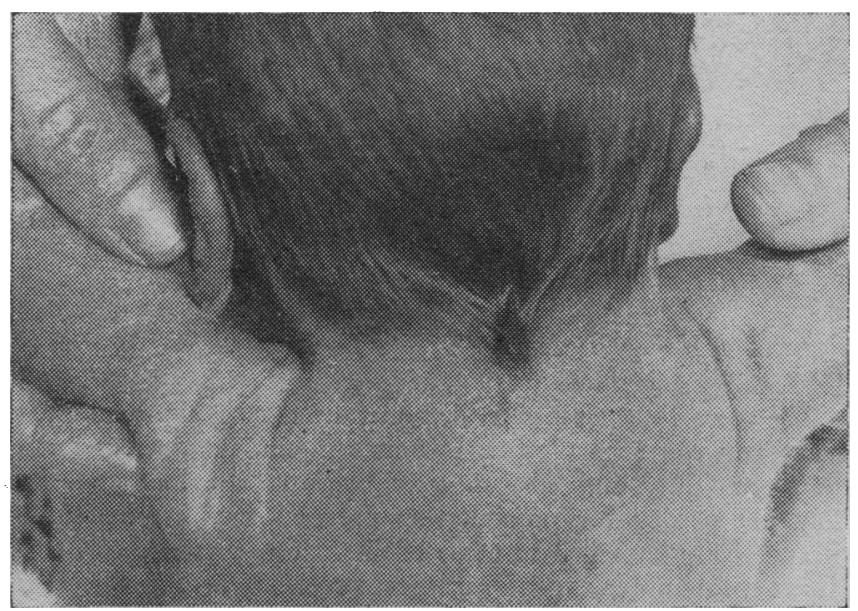

Fig. 4.-Case 3. Posterior view to show neck folds and low hair line.

Apart from oedema of feet (Fig. 5) and abnormal neck folds, which were presenting features in all but one case, the remaining Turner stigmata were of less significance. The nails were frequently covered by oedematous folds of skin so that they appeared very small, but their texture was usually normal. In one case the nails were absent from the fifth digit of each foot.

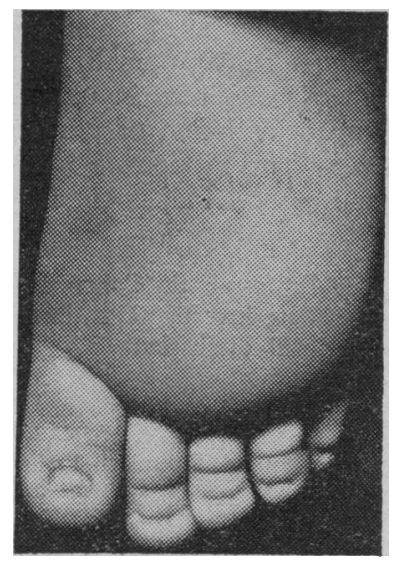

FIG. 5.- - Oedema of feet pits on pressure in spite of being a lymphoedema.

Sex Chromosomes.-All but one were chromatin-negative and eight of these were shown to have a $45 \mathrm{X}$ karyotype. The one who was chromatin-positive was a $45 \mathrm{X} / 46 \mathrm{XXqi}$ mosaic.

Streak gonads.-In all cases but one there was a sex chromosome constitution compatible with the presence of streak gonads, but only in the two who died did we confirm their presence. Fig. 6 shows clearly how much the neonatal streak gonad differs from a normal neonatal ovary.
The parents of the $45 \mathrm{X}$ children have already been advised that these children are liable to grow up to be small, that they may require replacement therapy at puberty, and that eventually they may be sterile.

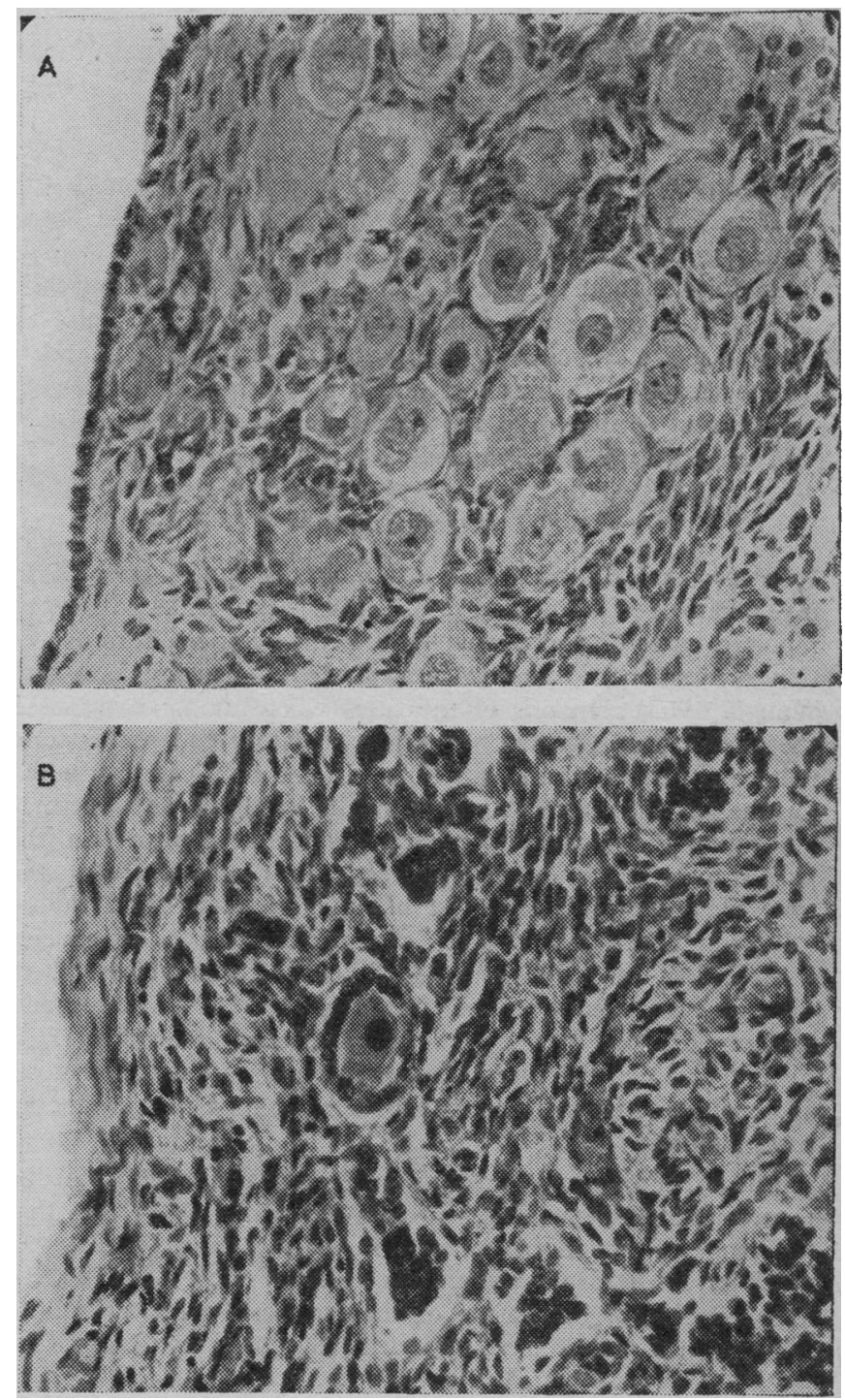

FIG. 6.-A, Normal neonatal ovary with many primordial follicles and scanty ovarian stroma. B, Streak gonad found in Case 4. There are few primordial follicles and the section consists almost entirely of ovarian stroma. The gonad in Case 7 was identical.

We wish to thank Mrs. P. Cook and Dr. C. E. Blank of the Sheffield Centre for Human Genetics for the cytogenetic studies ; also Professor R. S. Illingworth, Dr. J. Hunter, and Dr. W. J. Matheson for permission to include referred cases. Dr. J. L. Emery kindly provided the ovarian photomicrographs.

\section{REFERENCES}

Benson, P. F., Gough, M. H., and Polani, P. E. (1965). Arch. Dis. Childh., 40, 27

Carr, D. H., Haggar, R. A., and Hart, A. G. (1968). Amer. F. clin. Path.,

Conen, P. E., and Glass, I. H. (1963). F. clin. Endocr., 23, 1.

Ferguson-Smith, M. A. (1965). F. med. Genet., 2, 142.

Frøland, A., Lykke, A., and Zachau-Christiansen, B. (1963). Acta path. microbiol. scand., $57,21$.

Haddad, H. M., and Wilkins, L. (1959). Pediatrics, 23, 885.

Hodel, C., and Egli, F. (1965). Ann. paediat. (Basel), 204, 387.

Jacobs, P., and Keay, A. J. (1959). Lancet, 2, 732.

Jones, H. W., Turner, H. H., and Ferguson-Smith, M. A. (1966). Lancet, 1,1155 .

Nora, J. J., and Sinha, A. K. (1967). Lancet, 2, 256.

Polani, P. E. (1961). Brit. med. Bull., 17, 200.

Polani, P. E. (1961). Brit. med. Bull., 17, 200.

Wilkins, L. (1965). Diagnosis and Treatment of Endocrine Disorders in Childhood and Adolescence, 3rd ed., p. 272. Springfield, Iminois. Wilkins, L., and Fleischmann, W. (1944). f. clin. Endocr., 4, 357. 